\title{
SISTEM INFORMASI PELAYANAN DAN PELAPORAN SISWA SMAN 5 MATARAM
}

\author{
(Student Service and Reporting Information System of SMAN 5 Mataram) \\ Muhammad Naufal Rizqullah ${ }^{[1]}$, I Gede Pasek Suta Wijaya ${ }^{[1]}$, Novian Maududi ${ }^{[2]}$ \\ ${ }^{[1]}$ Program Studi Teknik Informatika, Universitas Mataram \\ Jl. Majapahit 62, Mataram, Lombok NTB, INDONESIA \\ ${ }^{[2]}$ Sekolah Menengah Atas Negeri 5 Mataram \\ Jl. Udayana No. 2A, Kec. Selaparang, Mataram, NTB \\ Email: m.naufalrizqullah17@gmail.com, gpsutawijaya@unram.ac.id,dodhie2015doa@gmail.com
}

\begin{abstract}
Abstrak
SMA Negeri 5 Mataram merupakan salah satu Sekolah Menengah Atas Negeri yang ada di Provinsi Nusa Tenggara Barat, Indonesia. Untuk peningkatan kualitas sekolah, SMA Negeri 5 Mataram bersama pegawai, guru dan petinggi melakukan pembahasan fasilitas dan hasil pengajaran dalam satu kali setahun. Pentingnya peningkatan kualitas membuat sekolah membutuhkan masukan berupa pelaporan atau keluhan dari para siswa. Untuk memudahkan sekolah dalam mendapatkan laporan dari siswa, perlu untuk dibuat sistem informasi yang dapat digunakan sebagai media bagi siswa untuk menyampaikan laporan atau keluhan. Maka dibuat Sistem Informasi Pelayanan dan Pelaporan Siswa berbasis web yang dirancang untuk memudahkan pihak sekolah dalam membantu siswa untuk menyampaikan laporan atau keluhannya. Sistem informasi ini dibangun menggunakan metode waterfall yang mencakup analisis, desain, pengkodean, pengujian dan pemeliharaan. Pembuatan sistem informasi ini menggunakan framework PHP yaitu Laravel dengan penyimpanan menggunakan basis data MySQL. Hasil dari kegiatan ini berupa sistem informasi pelayanan dan pelaporan siswa yang dapat membantu sekolah dalam menyediakan layanan dan laporan dari siwa untuk meningkatkan kualitas sekolah.
\end{abstract}

Keywords: Sistem Informasi, Pelayanan dan Pelaporan, Sekolah, Laravel, Waterfall.

\section{Pendahuluan}

Teknologi Informasi saat ini merupakan sebuah kebutuhan dalam melakukan setiap aktivitas di hampir setiap bidang, terutama di dalam sebuah instansi. Tuntutan setiap aktivitas ini yang menjadikan teknologi informasi sebagai bagian terpenting di dalam keberlangsungan kinerja yang sedang dijalankan oleh sebuah instansi.

Pentingnya peningkatan kualitas baik dari segi sarana dan prasarana maupun dari pengajarnya ini mengharuskan adanya sistem yang mampu membantu sekolah dalam memberikan masukan tentang apa saja yang masih menjadi kekurangan sekolah, dan maka itu dibutuhkan masukan dari pada siswa supaya sekolah mengetahui itu semua.

Tinjauan di lapangan bahwa sistem informasi pelaporan di SMA Negeri 5 Mataram sendiri masih belum ada. Untuk pelaporan sendiri selain biasanya dilakukan secara belum terbuka, bahkan baru dilaporkan jika dirasa sudah rusak (fasilitas) ataupun untuk siswanya masih malu / takut untuk melaporkan jika ada kekurangan.

Berdasarkan permasalahan tersebut dapat dibuat sebuah "Sistem Informasi Pelayanan dan Pelaporan Siswa" di SMA Negeri 5 Mataram yang diharapkan mampu mengatasi kekurangan fasilitas maupun SDM yang sering membuat siswa merasa kurang memadainya proses belajar mengajar pada SMA Negeri 5 Mataram serta bisa dilakukan tindakan yang cepat tanpa menunggu waktu yang lama.

Tujuan dari Praktek Kerja Lapangan ini adalah pembuatan sistem informasi pelayanan dan pelaporan siswa yang nantinya digunakan sebagai bahan pertimbangan sekolah dalam peningkatan fasilitas sekolah.

\section{Tinjauan Pustaka}

Menurut Rahmawati Nur Etika pada penelitian dengan judul Aplikasi Pelaporan Data Siswa Berbasis Web (Studi Kasus: SDN Telukan 02 Sukoharjo) yang pengembangannya menggunakan metode waterfall mengatakan bahwa Sistem informasi bermanfaat untuk memudahkan pekerjaan yang sebelumnya hanya dapat dilakukan secara sederhana menjadi lebih efisien, baik dalam pengelolaan data siswa, penyimpanan data siswa dan guru, serta pelaporan usia siswa [1]. 
Pada penelitian yang dilakukan oleh Arfan Haqiqi S. yang berjudul Sistem Informasi Pelaporan Nilai Berbasis SMS Gateway Pada SMA Negeri 3 Tegal mengatakan bahwa dengan dibuatnya sistem informasi pelaporan ini agar dalam penyampaian informasi lebih cepat, efisien, dan juga transparan kepada siswa [2].

Lalu pada penelitian yang dilaksanakan oleh Wildan Suharso dengan judul Sistem Informasi Pelaporan pada UPTD Pendidikan mengatakan sistem pelaporan yang sesuai dengan kebutuhan sangat diperlukan karena banyak permasalahan yang dapat diminimalisir jika pelaporan telah maksimal. Berdasarkan hasil pengujian didapatkan hasil sebesar 91\% dapat disimpulkan memudahkan UPTD dalam pengelolaan pelaporan [3].

Sistem informasi terdiri dari dua kata, yaitu sistem dan informasi. Sistem menurut Fat adalah sebuah himpunan "benda" nyata atau abstrak (a set of thing) yang terdiri dari bagian-bagian atau komponen-komponen yang saling berkaitan, berhubungan, ketergantungan, saling mendukung, yang secara keseluruhan bersatu dalam satu kesatuan (Unity) untuk mencapai suatu tujuan tertentu secara efisien dan efektif. Oleh sebab itu dapat disimpulkan bahwa sistem informasi adalah himpunan dari berbagai macam komponen-komponen yang saling berkaitan satu dengan lainnya yang berfungsi untuk melakukan pengolahan data dan informasi [4].

Pada basis data ini akan dibahas tentang definisi yang terdiri dari Database,File, Entity, dan Record. Penjelasannya sebagai berikut [5]:

a. Entity: Entity adalah orang, tempat, kejadian atau konsep yang informasinya direkam pada suatu basis data misalnya informasi lalu lintas, entity antara lain kemacetan, kecelakaan dan lain sebagainya.

1. Atribut: Setiap entity mempunyai atribut atau sebutan untuk mewakili suatu entity lalu lintas dengan atributnya, misalnya nama obyek, alamat, jenis obyek, dan lain sebagainya. Atribut juga disebut sebagai data elemen, data field, item.

2. Data Value: Data value adalah data aktual atau informasi yang disimpan pada tiap data elemen atau atribut.

b. Database: Database adalah kumpulan field-field yang mempunyai kaitan antara satu file dengan field yang lain sehingga membentuk bangunan data untuk menginformasikan kondisi lalu lintas dalam bahasa tertentu.

c. File: File adalah kumpulan record-record sejenis yang mempunyai Panjang elemen yang sama, atribut yang sama, namun berbeda-beda datanya [5].

Entity relationship (ER) data model didasarkan pada persepsi terhadap dunia nyata yang tersusun atas kumpulan objek-objek dasar yang disebut entitas dan hubungan antar objek. Entitas adalah sesuatu atau objek dalam dunia nyata yang dapat dibedakan dari objek lain. Misal: mahasiswa, dan mata kuliah. Entitas digambarkan dalam basis data dengan kumpulan atribut. Misalnya: nim, nama, alamat, dan kota. Relasi adalah hubungan antara beberapa entitas. Misalnya: relasi menghubungkan mahasiswa dengan mata kuliah yang diambilnya. Struktur logis (skema database) dapat ditunjukkan secara grafis dengan diagram ER yang dibentuk dari komponen-komponen berikut [6]:

a. Entitas: suatu yang nyata atau abstrak yang mempunyai karakteristik di mana kita akan menyimpan data [7]. Entitas dibedakan menjadi dua jenis yaitu [8]:

1. Entitas kuat (strong entity), yaitu suatu entitas yang keberadaannya tidak tergantung dengan entitas lainnya.

2. Entitas lemah (weak entity), yaitu suatu entitas yang keberadaanya bergantung dengan entitas lainnya.

b. Atribut: ciri umum semua atau sebagian besar instansi pada entitas tertentu [7]. Berikut merupakan jenisjenis atribut yang ada $[8]$ :

1. Simple attribute, yaitu atribut yang nilainya tidak dapat dibagi menjadi bentuk yang lebih kecil.

2. Composite attribute, yaitu atribut yang nilainya dapat dibagi menjadi bagian yang lebih kecil.

3. Single valued attribute, yaitu atribut yang hanya boleh mengandung satu nilai tertentu.

4. Multi valued attribute, yaitu atribut yang boleh mengandung boleh lebih dari satu nilai.

5. Derivated attribute, yaitu atribut yang nilainya diperoleh dari dua atau lebih atribut.

c. Relasi: hubungan alamiah yang terjadi antara satu atau lebih entitas [7]. Relasi tidak memiliki keberadaan

fisik, melainkan mewarisi hubungan antara entitas tersebut [8].

d. Link: garis penghubung atribut dengan kumpulan entitas dan kumpulan entitas dengan relasi [7].

Usecase diagram merupakan diagram yang menggambarkan kelakuan (behavior) sistem informasi yang dibuat. Usecase diagram digunakan untuk mengetahui fungsi apa saja yang terdapat di dalam sistem dan siapa saja yang berhak melakukan fungsi-fungsi tersebut [8].

Activity diagram berfungsi untuk menggambarkan aliran kerja atau aliran aktivitas dari suatu sistem [8]. Menggambarkan rangkaian aliran dari aktivitas, digunakan untuk mendeskripsikan aktivitas yang dibentuk dalam suatu operasi sehingga dapat juga digunakan untuk aktivitas lainnya. Diagram ini sangat mirip dengan flowchart karena memodelkan workflow dari satu aktivitas ke aktivitas lainnya. Pembuatan activity pada awal pemodelan proses dapat membantu memahami keseluruhan proses. Activity diagram juga digunakan untuk menggambarkan interaksi antara beberapa usecase [9]. 
Sequence diagram terdiri atas dimensi vertical (waktu) dan dimensi horizontal (objek-objek terkait) yang menggambarkan interaksi antar objek didalam maupun sekitar sistem serta skenario atau langkah-langkah yang dilakukan sebagai respon dari suatu event untuk menghasilkan output tertentu [9].

Laravel adalah sebuah framework web berbasis PHP yang open-source dan tidak berbayar, diciptakan oleh Taylor Otwell dan diperuntukkan untuk pengembangan aplikasi web yang menggunakan pola MVC. Struktur pola MVC pada laravel sedikit berbeda pada struktur pola MVC pada umumnya [10]. Laravel banyak memiliki fitur modern yang sangat membantu dalam membuat aplikasi. Beberapa fitur diantaranya adalah Eloquent ORM (Object Relational Mapping), Bundles, Blade, Migration, Query Builder, Middleware Resource Controller, dan Automatic Pagination. Framework Laravel juga memiliki keunggulan seperti menggunakan Command Line Interface (CLI) Artisan, dan menggunakan package manager PHP Composer [11].

MySQL merupakan sebuah open source relational database management system (RDBMS) dimana server ini memberikan layanan basis data SQL (Structured Query Language) yang sangat cepat multithreaded, multipengguna, dan kuat [12]. MySQL AB membuat MySQL tersedia sebagai perangkat lunak gratis di bawah lisensi GNU General Public License (GPL), tetapi mereka juga menjual dibawah lisensi komersial untuk kasus-kasus dimana penggunaannya tidak cocok dengan penggunaan GPL [13]. Beberapa keunggulan dari MySQL yaitu [14]:

a. Cepat, handal dan mudah dalam penggunaannya MySQL lebih cepat tiga sampai empat kali dari pada database server komersial yang beredar saat ini, mudah diatur dan tidak memerlukan seseorang yang ahli untuk mengatur administrasi pemasangan MySQL.

b. Didukung oleh berbagai bahasa Database server MySQL dapat memberikan pesan error dalam berbagai bahasa seperti Belanda, Portugis, Spanyol, Inggris, Perancis, Jerman, dan Italia.

c. Mampu membuat tabel berukuran sangat besar dan ukuran maksimal dari setiap tabel yang dapat dibuat dengan MySQL adalah 4 GB sampai dengan ukuran file yang dapat ditangani oleh sistem operasi yang dipakai.

d. Lebih Murah MySQL bersifat open source dan didistribusikan dengan gratis tanpa biaya untuk UNIX platform, OS/2 dan Windows platform.

e. Melekatnya integrasi PHP dengan MySQL, keterikatan antara PHP dengan MySQL yang sama-sama software opensource sangat kuat, sehingga koneksi yang terjadi lebih cepat jika dibandingkan dengan menggunakan database server lainnya. Modul MySQL di PHP telah dibuat built-in sehingga tidak memerlukan konfigurasi tambahan pada file konfigurasi php.ini.

\section{PELAKSANAAN PRAKTEK KERJA LAPANGAN}

Pelaksanaan Praktek kerja lapangan di SMA Negeri 5 Mataram memiliki beberapa tahapan dalam proses pembuatan sistemnya yaitu metode perancangan sistem, desain sistem dan impelemtasi sistem. Berikut ini adalah tahapan proses dalam pembuatan sistem informasi pelayanan dan pelaporan SMA Negeri 5 Mataram.

\subsection{Metode Perancangan Sistem}

Metode waterfall digunakan sebagai dasar pengembangan sistem yang akan dibangun. Metode waterfall memungkinkan pengerjaan sistem yang dilakukan secara linear atau secara berurutan. Setiap langkah-langkah pengerjaan harus dikerjakan berurutan tanpa bisa dilewati. Apabila langkah pertama belum dikerjakan, maka sangat tidak memungkinkan untuk mengerjakan langkah selanjutnya. Sehingga untuk menyelesaikan pengembangan sistem, sebuah keharusan bahwa penyelesaian setiap langkah pekerjaan harus diselesaikan dengan tuntas. Tahapan metode waterfall dapat dilihat pada Gambar 1 [15].

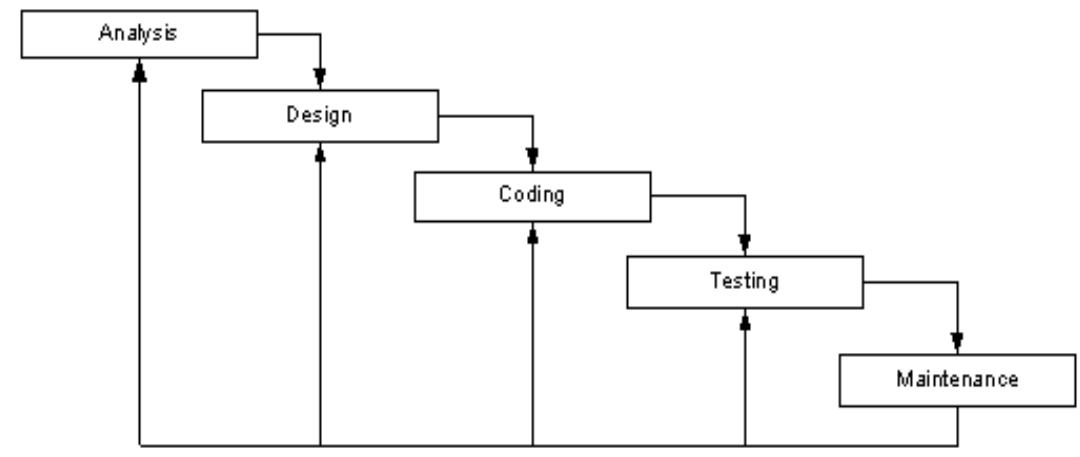

Gambar 1. Model Waterfall 


\subsection{Desain Sistem Informasi Pelayanan dan Pelaporan}

Pada sistem informasi pelayanan dan pelaporan siswa SMA Negeri 5 Mataram ini terdapat dua diagram yaitu usecase diagram, dan entity relationship diagram, berikut penjelasannya.

\subsubsection{Usecase Diagram}

Berikut ini merupakan usecase digaram dari sistem informasi pelayanan dan pelaporan siswa SMA Negeri 5 Mataram yang ditunjukan pada Gambar 2.

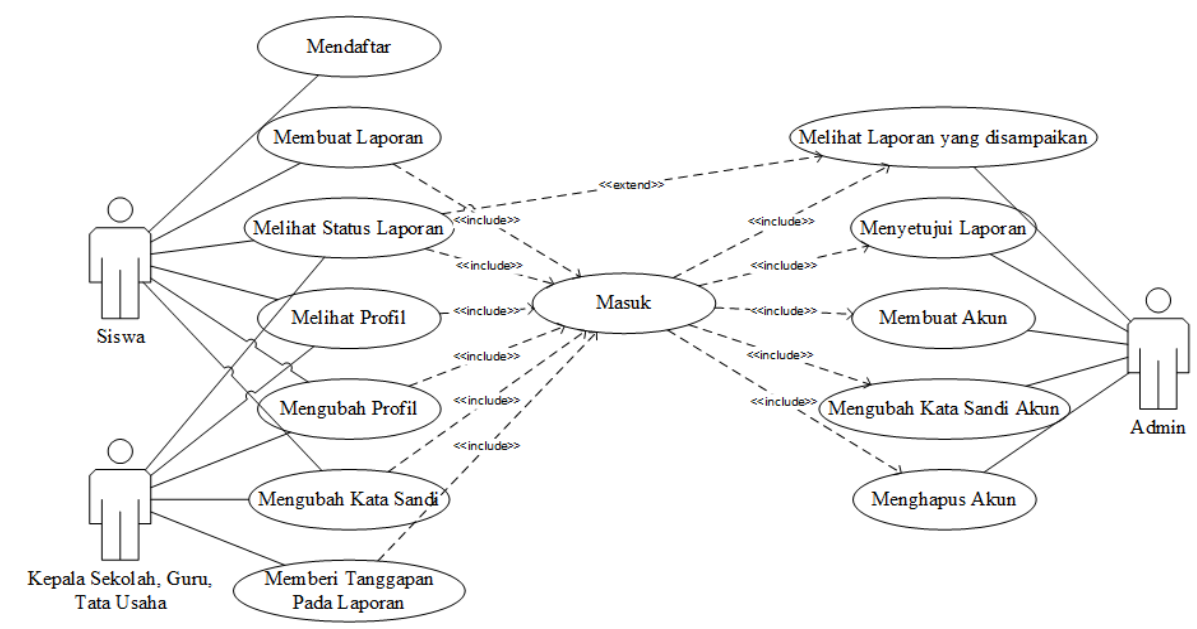

Gambar 2. Usecase Diagram

Pada usecase diagram di Gambar 2 ini memiliki 3 user yang akan dijelasakan beserta dengan perilakunya sebagai berikut:

a. Siswa

User Siswa dapat melakukan proses pengolahan data seperti berikut :

1. Mendaftar ke dalam system

2. Masuk ke dalam system

3. Membuat laporan

4. Melihat status laporan

5. Melihat profil

6. Mengubah profil

7. Mengubah Kata sandi

b. Kepala Sekolah, Guru, Tata Usaha

User Kepala Sekolah, Guru, Tata Usaha dapat melakukan proses pengolahan data seperti berikut :

1. Masuk ke dalam system

2. Melihat status laporan

3. Melihat profil

4. Mengubah profil

5. Mengubah Kata sandi

6. Memberi tanggapan pada laporan

c. Admin

User Admin dapat melakukan proses pengolahan data seperti berikut :

1. Masuk ke dalam system

2. Melihat laporan yang disampaikan

3. Menyetujui Laporan

4. Membuat Akun

5. Mengubah kata sandi akun

6. Menghapus akun 


\subsubsection{ERD}

Berikut pada Gambar 3 adalah ERD (entity relationship diagram) dari sistem informasi pelayanan dan pelaporan siswa SMA Negeri 5 Mataram.

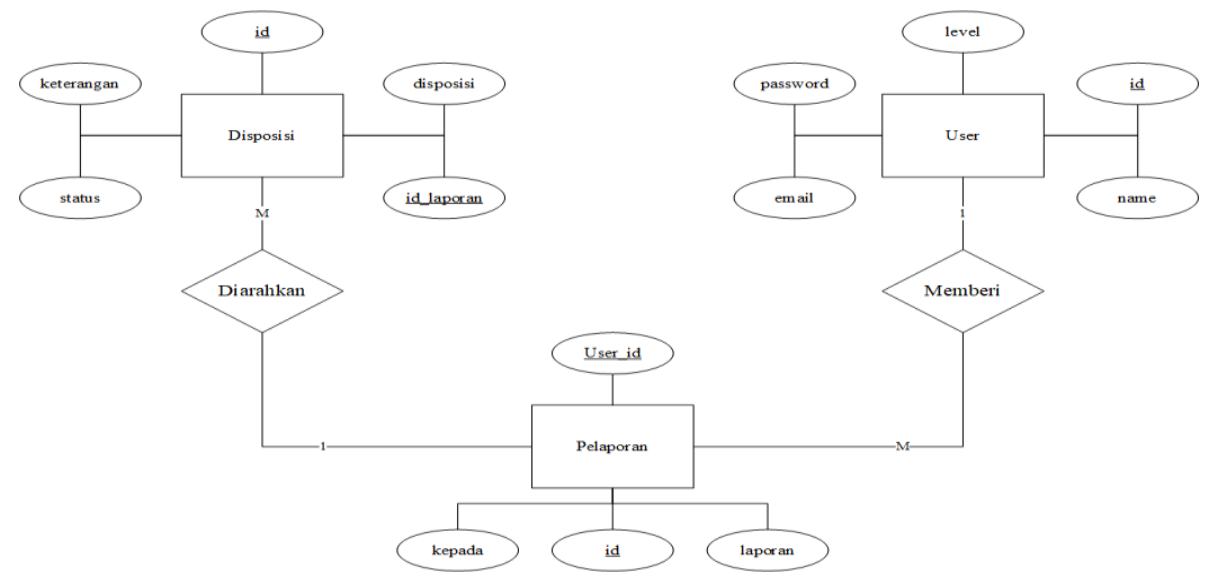

Gambar 3. ERD sistem informasi pelayanan dan pelaporan

Pada ERD di Gambar 3 dimana terdapat tiga entitas yaitu user, pelaporan dan disposisi. Untuk entitas user memiliki atribut id, name, level, password dan email. Lalu untuk entitas pelaporan memiliki atribut id, kepada, pelaporan dan User_id. Lalu entitas disposisi memiliki atribut id, disposisi, keterangan, status, dan id_laporan. Relasi yang terjadi pada ERD ini terdapat pada entitas user dan pelaporan dimana relasi yang terjadi adalah 1 to many, dan juga pada entitas pelaporan dan disposisi dimana relasi yang terjadi adalah many to 1 .

\subsection{Impelemtasi Sistem Informasi Pelayanan dan Pelaporan}

\subsubsection{Implementasi Perangkat Keras}

Perangkat keras yang digunakan dalam pembuatan sistem ini akan menentukan bagiamana jalannya sistem baik dalam segi kecepatan pengolahan data maupun ketahanan data tersebut. Adapun perangkat keras yang minimal dibutuhkan adalah sebagai berikut:
a. Processor Intel i3 4005u (Disarankan lebih tinggi)
b. Ram : 2GB (Disarankan lebih tinggi)
c. Hardisk : Minimal 20GB
d. Internet: minimal $128 \mathrm{Kbps}$ atau lebih tinggi lebih baik
e. Alat pendukung seperti Mouse, Keyboard Monitor

\subsubsection{Implementasi Perangkat Lunak}

Selain perangkat keras, perangkat lunak pun harus disiapkan dalam membangun sistem ini, yaitu dengan menggunakan software penunjang, antara lain:

a. Database Server

Dalam pengelolaan database, server database yang digunakan adalah MySQL dari perangkat lunak XAMPP. Didalam XAMPP terdapat seperti Apache, MySQL, dan lain lain. Dimana didalam XAMPP ini sudah terdapat PHP sebagai including dari Apache sendiri untuk memudahkan dalam melakukan pengelolaan database itu sendiri.

b. Code Editor

Untuk penulisan script / code dari sistem yang dibuat, digunakan perangkat lunak Visual Studio Code (VS Code). Dimana VS Code ini digunakan untuk menulis code Laravel, PHP, maupun dari web nya sendiri.

c. Browser

Dalam proses pembuatan sistem, media browser yang digunakan sebagai tempat dijalankannya suatu sistem adalah browser Mozilla Firefox.

\subsubsection{Implementasi Framework}

Dalam pembuatan sistem ini, digunakan framework yaitu Laravel. Laravel merupakan framework yang berasal dari PHP yang dikembangkan oleh Taylor Otwell. Sistem ini menggunakan laravel versi 6.x. Pada akhir pembuatan sistem ini versi terakhir laravel yang digunakan adalah 6.16.0. 


\section{Hasil dan Pembahasan}

Pada kegiatan ini dihasilkan suatu Sistem Informasi Pelayanan dan Pelaporan Siswa SMA Negeri 5 Mataram dan hasil pengujiannya. Berikut diuraikan hasil pembahasan terperincinya.

\subsection{Hasil Akhir Sistem}

Berikut pada gambar adalah hasil akhir program dari sistem informasi pelayanan dan pelaporan siswa SMA Negeri 5 Mataram.

a. Halaman Utama

Pada Gambar 4 merupakan implementasi dari halaman utama. Halaman utama ini berfungsi sebagai halaman awal saat di kunjungi oleh user.

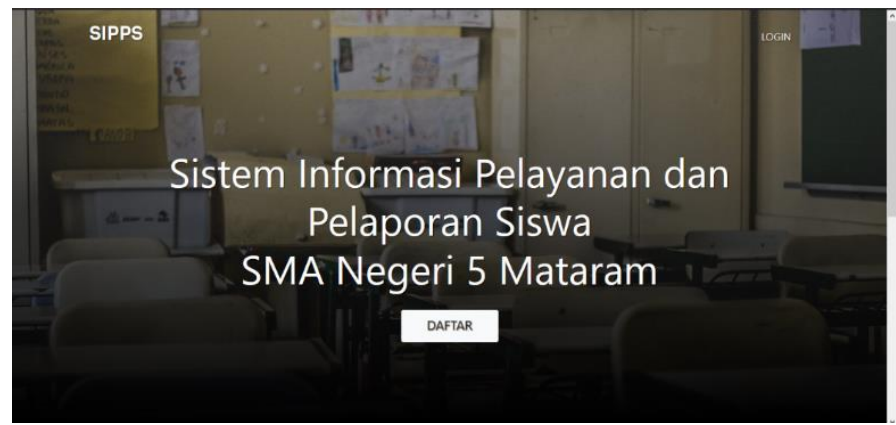

Gambar 4. Halaman Utama

Pada Halaman ini terdapat tombol masuk pada navigation bar, lalu tombol daftar untuk ke halaman daftar selain itu user juga dapat melihat gambar SMA Negeri 5 Mataram beserta mottonya.

b. Halaman Login

Pada Gambar 5 merupakan implementasi dari halaman login yang merupakan cara user untuk masuk kedalam sistem. Halaman ini bisa dicapai dengan menekan tombol login pada navigation bar.

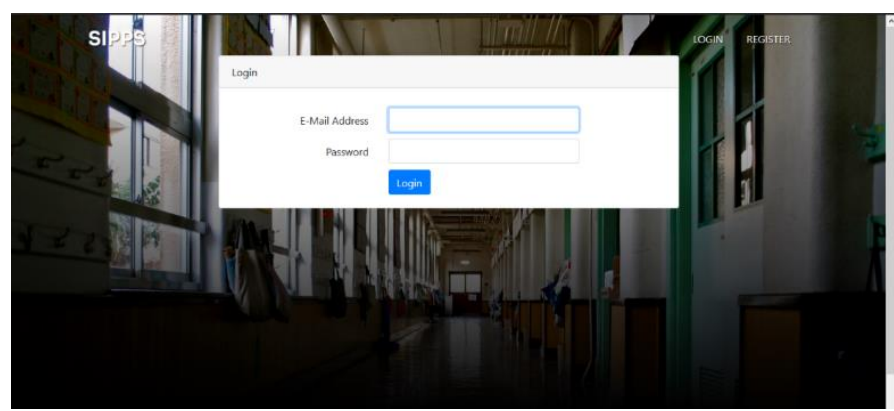

Gambar 5. Halaman Login

Pada halaman ini berfungsi sebagai cara user untuk masuk kedalam sistem dengan memasukan email dan juga kata sandi. Lalu setelah login maka secara otomatis akan dialihkan ke halaman home.

c. Halaman Register

Pada Gambar 6 merupakan implementasi dari halaman register yang merupakan cara user untuk mendaftar kedalam sistem. Halaman ini bisa dicapai dengan menekan tombol register pada navigation bar atau pada tombol daftar di halaman utama.

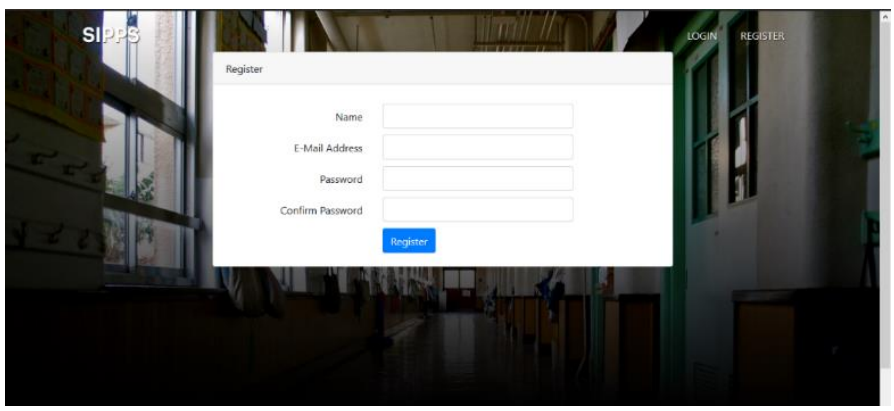

Gambar 6. Halaman Register 
Pada halaman ini digunakan user sebagai tempat untuk mendaftarkan diri ke dalam sistem jika belum mempunyai akun. Dengan mengisikan nama, email dan kata sandi pada form yang tersedia. Lalu setelah mendaftar maka secara otomatis akan dialihkan ke halaman home.

d. Halaman Home pada User Siswa

Pada Gambar 7 merupakan implementasi dari halaman home ketika user siswa telah masuk. Halaman ini bisa dicapai dengan cara masuk menggunakan user siswa pada halaman login.

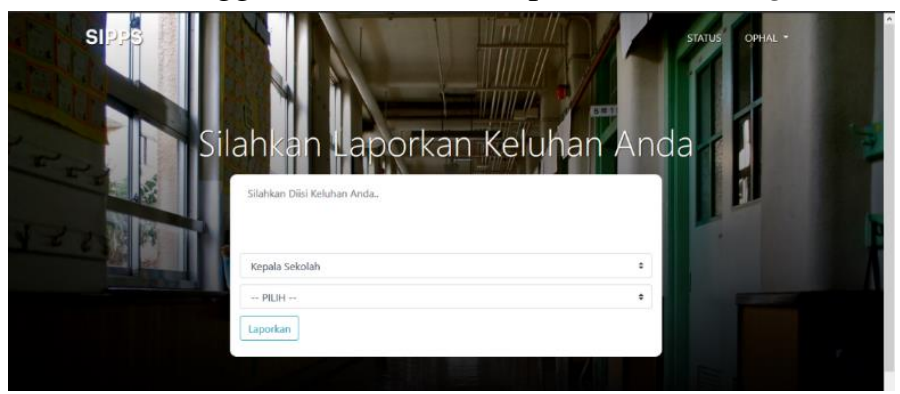

Gambar 7. Home pada User Siswa

Pada halaman ini terdapat form untuk melakukan pelaporan yang ditujukan kepada kepala sekolah, guru maupun tata usaha, dan dan juga di navigation bar terdapat tombol status untuk melihat laporan yang terkirim serta profile dan juga logout.

e. Halaman Status pada User Siswa

Pada Gambar 8 merupakan implementasi dari status. Halaman ini bisa dicapai dengan cara menekan tombol status pada navigation bar di halaman home.

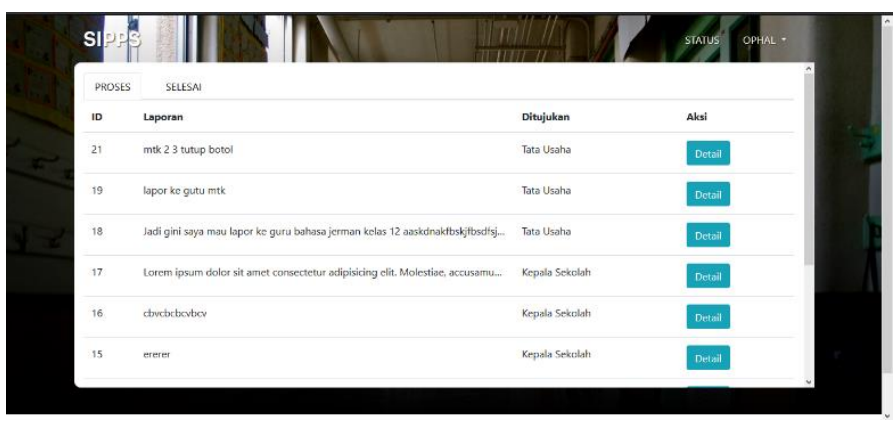

Gambar 8. Halaman Status pada User Siswa

Pada halaman ini terdapat semua laporan user yang disajikan dalam dua tab yaitu tab proses dan tab selesai, lalu terdapat form digunakan untuk melihat apa saja yang telah dilaporkan oleh user, lalu tombol detail pada setiap laporan berfungsi jika ingin melihat detail laporan apakah masih didalam proses atau sudah ditolak.

f. Halaman Profile pada User Siswa

Pada Gambar 9 merupakan implementasi dari profile. Halaman ini bisa dicapai dengan cara menekan tombol dropdown profile pada navigation bar di halaman home.

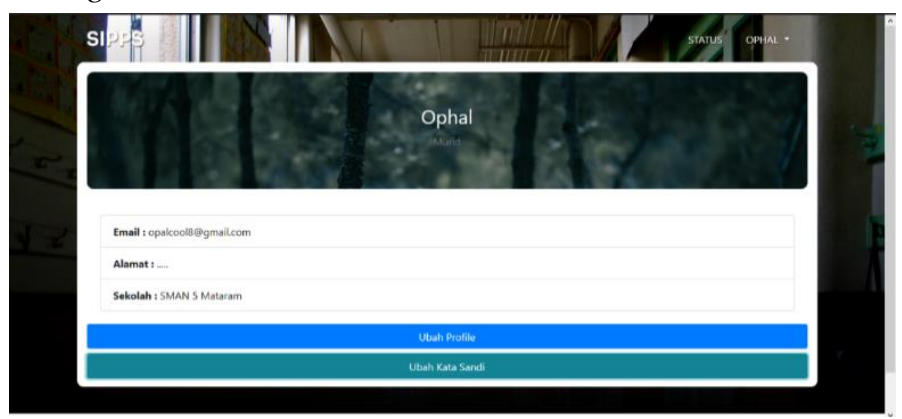

Gambar 9. Halaman Profile pada User Siswa

Pada halaman ini terdapat informasi mengenai user, lalu tombol untuk ubah profile untuk mengubah profile dan tombol ubah kata sandi untuk mengubah kata sandi. 
g. Halaman Ubah Profile pada User Siswa

Pada Gambar 10 merupakan implementasi dari ubah profile. Halaman ini bisa dicapai dengan cara menekan tombol dropdown profile pada navigation bar di halaman home, lalu menekan tombol ubah profile.

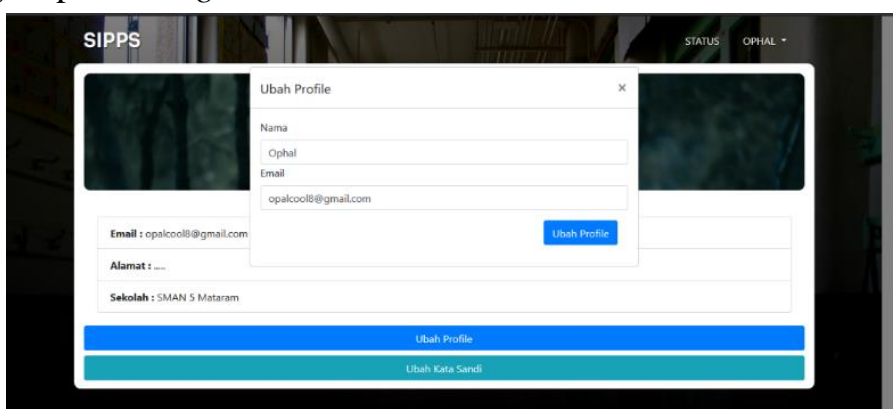

Gambar 10.Halaman Ubah Profile pada User Siswa

Pada halaman ini terdapat form untuk mengubah profile, dimana jika form tersebut dilakukan perubahan baik dari nama atau pun email, jika ditekan tombol simpan maka perubahan tersebut akan tersimpan ke database.

h. Halaman Ubah Kata Sandi pada User Siswa

Pada Gambar 11 merupakan implementasi dari ubah kata sandi. Halaman ini bisa dicapai dengan cara menekan tombol dropdown profile pada navigation bar di halaman home, lalu menekan tombol ubah kata sandi.

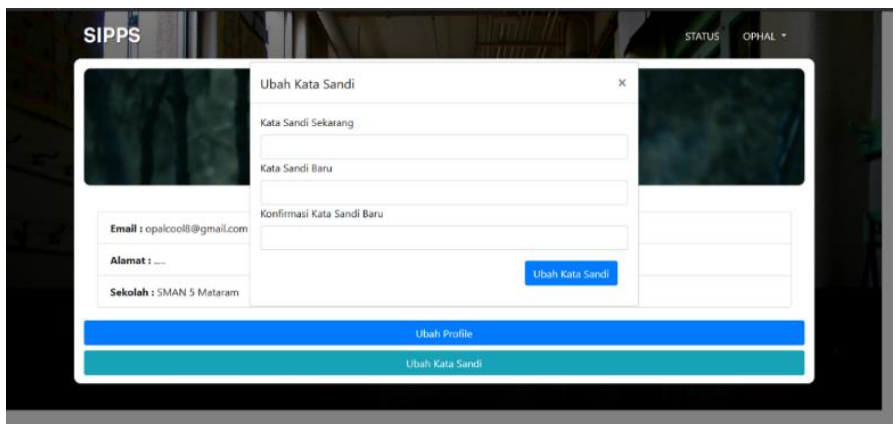

Gambar 11.Halaman Ubah Kata Sandi pada User Siswa

Pada halaman ini terdapat form untuk mengubah kata sandi lalu nantinya untuk merubah kata sandi dimulai dengan memasukan kata sandi yang sekarang, lalu memasukan kata sandi baru disertai dengan konfirmasi kata sandi, nantinya untuk menyimpan perubahan bisa dengan menekan tombol ubah kata sandi.

i. Halaman Home pada User Kepala Sekolah, Guru, Tata Usaha

Pada Gambar 12 merupakan implementasi dari halaman home ketika user Kepala Sekolah, Guru, Tata usaha telah masuk. Halaman ini bisa dicapai dengan cara masuk menggunakan user Kepala Sekolah, Guru, Tata Usaha pada halaman login.

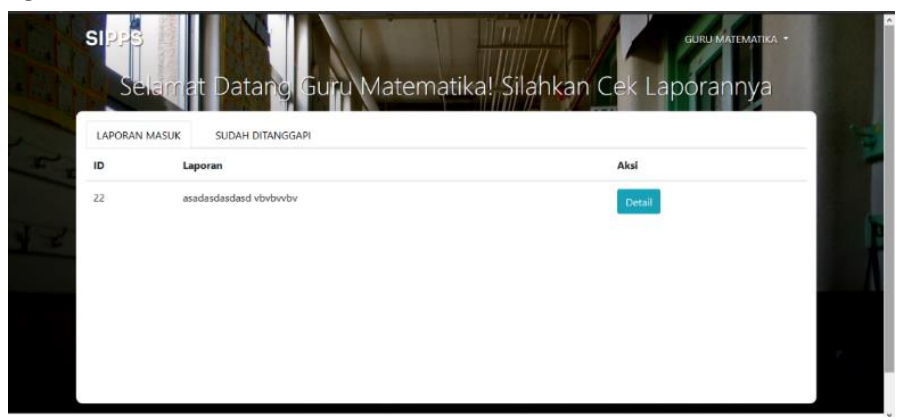

Gambar 12.Halaman Home pada User Kepala Sekolah, Guru, Tata Usaha

Pada halaman ini terdapat form untuk laporan apa saja yang telah masuk dan apa saja yang telah ditanggapi, dan dilengkapi dengan tombol detail untuk melihat lebih detail laporan yang diberikan. 
j. Halaman Dashboard Admin

Pada Gambar 13 merupakan implementasi dari halaman dashboard ketika admin telah masuk. Halaman ini bisa dicapai dengan cara masuk menggunakan user Admin pada halaman login.

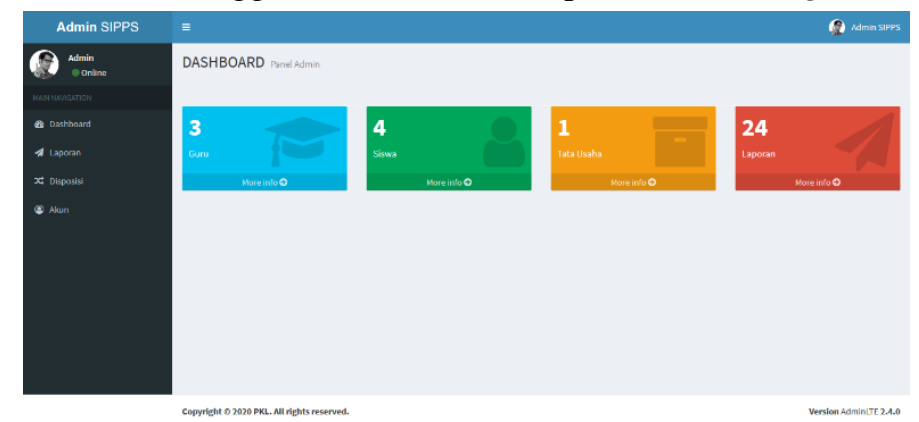

Gambar 13.Halaman Dashboard Admin

Pada halaman ini berfungsi sebagai tampilan awal admin, dimana terdapat berbagai informasi dasar seperti jumlah siswa yang mendaftar ke sistem, jumlah guru, jumlah tata usaha dan jumlah dari laporan yang sudah masuk kedalam sistem.

k. Halaman Laporan pada Admin

Pada Gambar 14 merupakan implementasi dari halaman laporan admin. Halaman ini bisa dicapai dengan cara menekan tombol laporan di sidebar navigation.

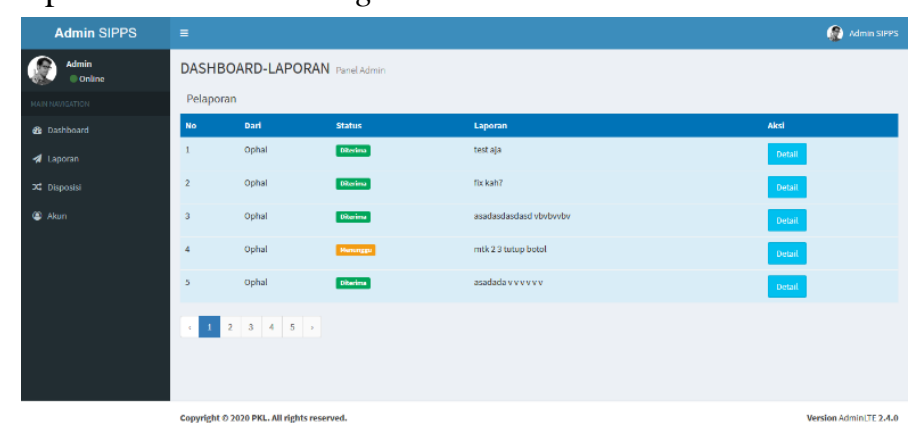

Gambar 14.Halaman Laporan pada Admin

Pada halaman ini berfungsi sebagai tempat semua laporan masuk, dan menampilkan status dari laporan itu sendiri dan juga tombol untuk memasuki detail dari laporan tersebut.

1. Halaman Detail Laporan pada Admin

Pada Gambar 15 merupakan implementasi dari halaman detail laporan admin. Halaman ini bisa dicapai dengan cara menekan tombol detail pada suatu laporan di halaman laporan.

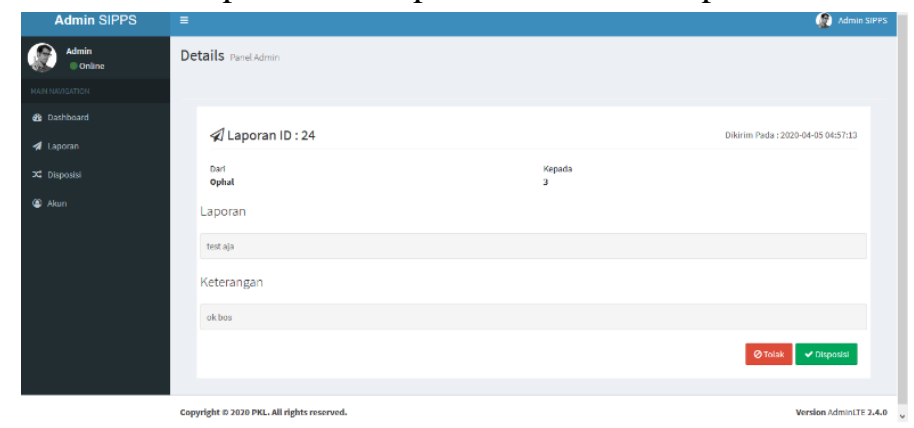

Gambar 15.Halaman Detail Laporan pada Admin

Pada halaman ini berfungsi sebagai informasi dari suatu laporan, dimana menampilkan laporan itu sendiri, tujuan laporannya dll. Lalu terdapat 2 tombol aksi yaitu disposisi yang berfungsi sebagai konfirmasi laporan itu di terima dan tombol tolak yang berfungsi untuk menolak laporan tersebut.

m. Halaman Disposisi pada Admin

Pada Gambar 16 merupakan implementasi dari halaman disposisi admin. Halaman ini bisa dicapai dengan cara menekan tombol disposisi di sidebar navigation. 


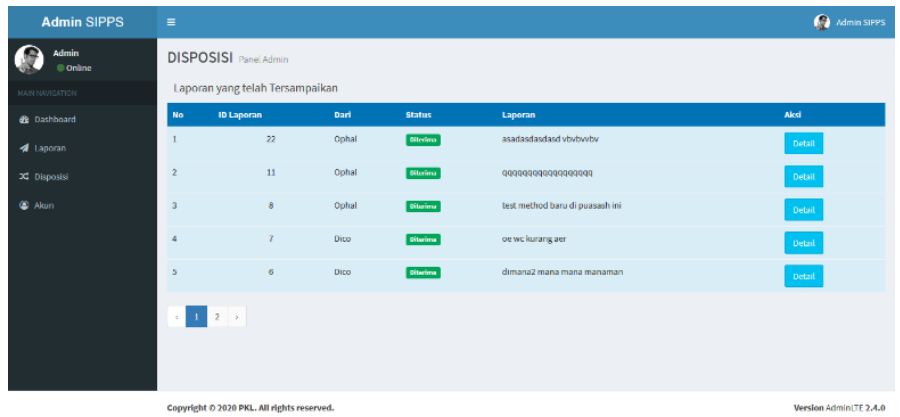

Gambar 16.Halaman Disposisi pada Admin

Pada halaman ini menampilkan laporan apa aja yang telah disetujui, dan juga melihat tanggapan yang diberikan oleh kepala sekolah, guru ataupun tata usaha.

n. Halaman Akun pada Admin

Pada Gambar 17 merupakan implementasi dari halaman akun admin. Halaman ini bisa dicapai dengan cara menekan tombol akun di sidebar navigation.

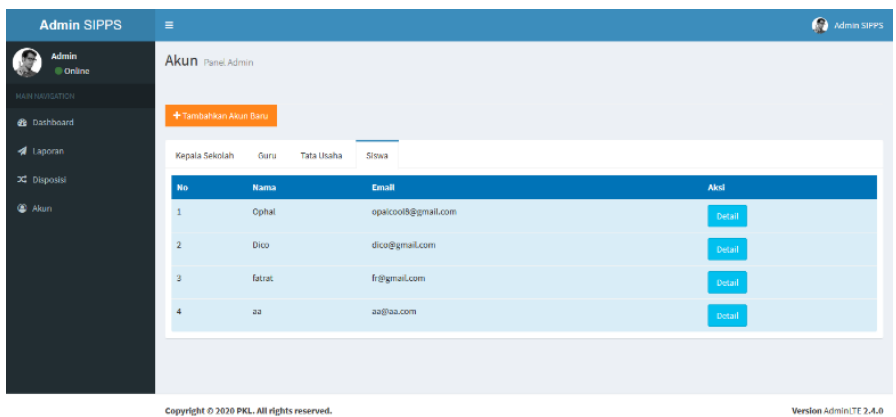

Gambar 17.Halaman Akun pada Admin

Pada halaman ini menampilkan semua user yang ada didalam sistem. Dalam halaman ini juga terdapat tombol untuk membuat akun baru. Lalu pada tombol detail nantinya akan menampilkan detail dari suatu akun.

o. Halaman Detail Akun pada Admin

Pada Gambar 18 merupakan implementasi dari halaman detail akun admin. Halaman ini bisa dicapai dengan cara menekan tombol tambahkan akun baru di halaman akun.

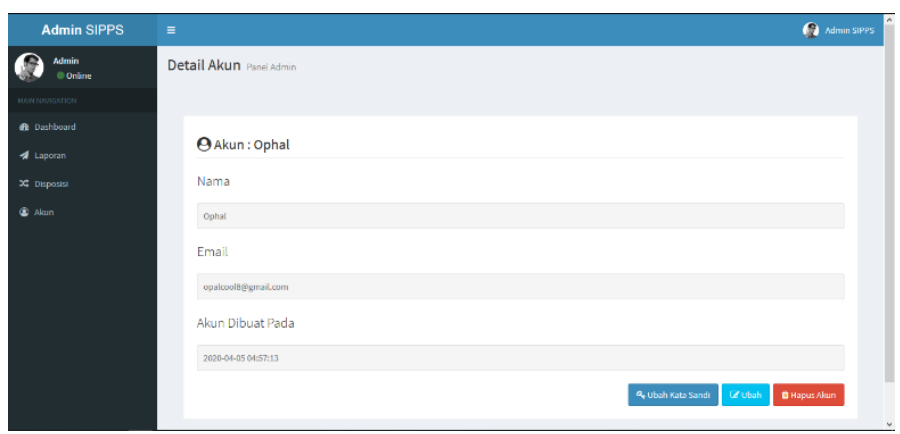

Gambar 18.Halaman Detail Akun pada Admin

Pada halaman ini menampilkan detail dari suatu user. Terdapat 3 tombol yaitu ubah kata sandi yang berfungsi untuk mengubah kata sandi, lalu tombol edit yang berfungsi untuk mengubah profile dari akun tersebut, dan tombol hapus akun yang berfungsi untuk menghapus akun dari sistem.

\subsection{Hasil Pengujian}

Setelah dilakukan pengimplementasian sistem, selanjutnya dilakukan pengujian sistem. Pengujian sistem ini dilakukan dengan menggunakan kuesioner yang dilakukan dengan membagikan kuesioner kepada guru atau pegawai di SMA Negeri 5 Mataram untuk melakukan percobaan dan pengujian sistem. Lalu setelah itu diberikan kuesioner dengan pertanyaan sebagai berikut: 
a. Apakah Sistem yang dibuat mudah digunakan?

b. Apakah Sistem yang dibuat sudah bisa membantu mempermudah sekolah dalam meningkatkan kualitasnya?

c. Apakah Sistem yang dibuat sudah baik dalam segi fungsionalitasnya?

d. Apakah Sistem yang dibuat sudah memenuhi kebutuhan instansi?

e. Apakah Sistem yang dibuat sudah membantu siswa dalam penyampaian keluhan ke sekolah?

Setelah diberikan pertanyaan, maka jawaban untuk dari pertanyaan-pertanyaan kuesioner tadi adalah:

a. Sangat Setuju

b. Setuju

c. Cukup

d. Tidak Setuju

e. Sangat Tidak Setuju

Setelah diberikan kuesioner kepada responden, berikut adalah hasil dari jawaban yang diberikan oleh responden yang disajikan dalam bentuk grafik pada Gambar 19

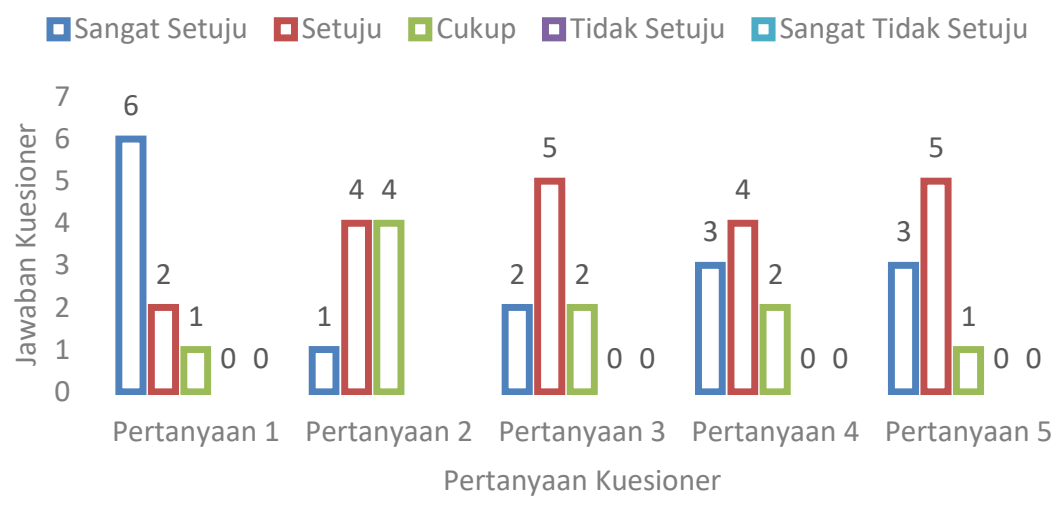

Gambar 19.Grafik Rekapitulasi Hasil Pengujian

Berdasarkan jawaban kuesioner yang diberikan oleh para guru atau pegawai pada Gambar 19 menampilkan grafik hasil rekapitulasi jawaban berdasarkan 9 orang yang mengisi kuesioner tersebut. Dengan hasil kuesioner ini dan juga konsultasi dengan kepala Lab. TIK SMA Negeri 5 Mataram bisa disimpulkan bahwa sistem ini disetujui oleh pihak sekolah.

\section{KESIMPULAN DAN SARAN}

\subsection{Kesimpulan}

Berdasarkan hasil Praktek Kerja Lapangan SMA Negeri 5 Mataram berupa Sistem Informasi Pelayanan dan Pelaporan Siswa, maka didapatkan kesimpulan sebagai berikut :

a. Sistem Informasi Pelayanan dan Pelaporan Siswa telah berjalan sebagaimana mestinya dan dapat membantu SMA Negeri 5 Mataram dalam menyelesaikan masalah peningkatan fasilitas sekolah yang membutuhkan masukan dari siswa agar sekolah dapat memberikan fasilitas yang terbaik dan tepat sasaran.

b. Rancangan Sistem Informasi Pelayanan dan Pelaporan dibuat berdasarkan hasil analisis dari kebutuhan sekolah mengenai peningkatan kualitas sekolah.

\subsection{Saran}

Adapun saran yang dapat diberikan penulis agar Sistem Informasi Pelayanan dan Pelaporan ini menjadi lebih baik di masa yang akan datang adalah sebagai berikut:

a. Perlunya dilakukan pengembangan sistem yang lebih baik terutama dalam hal fitur laporan supaya lebih baik dalam penyampaian laporannya.

b. Dalam pengembangan selanjutnya, diharapkan Sistem Informasi Pelayanan dan Pelaporan dapat menjadi lebih kompleks dalam fungsi maupun fasilitas yang diberikan supaya mendapatkan hasil yang lebih baik kedepannya. 


\section{UCAPAN TERIMA KASIH}

Dalam penyusunan jurnal PKL ini penulis ingin mengucapkan terima kasih kepada Kepala Sekolah SMA Negeri 5 Mataram yaitu Bapak Drs. H. Arofiq, M.M. yang sudah menerima penulis untuk pelaksanaan PKL di SMA Negeri 5 Mataram. Lalu kepada Bapak Novian Maududi, S. Kom. yang sudah membimbing penulis di lapangan dalam pelaksanaan dan pengerjaan PKL, dan juga kepada bapak/ibu guru, karyawan yang sudah membantu dalam pelaksanaan PKL ini. Dan tidak lupa pula semua pihak yang telah membantu penulis yang tidak dapat penulis sebutkan satu persatu yang telah membantu selama pelaksanaan PKL ini.

\section{DAFTAR PUSTAKa}

[1] R. N. Etika, "Aplikasi Pelaporan Data Siswa Berbasis Web ( Studi Kasus : Sdn Telukan 02 Sukoharjo )," Univ. Muhammadiyah Surakarta, pp. 1-13, 2017, [Online]. Available: https://repository.bsi.ac.id/index.php/repo/viewitem/203.

[2] A. H. Sulasmoro, Rais, and V. S. Salam, "Sistem Informasi Pelaporan Nilai Berbasis SMS Gateway Pada SMA Negeri 3 Tegal," SMART COMP J. Orang Pint. Komput., vol. 6, no. 2, pp. 212-216, 2017, [Online]. Available: http://ejournal.poltektegal.ac.id/index.php/smartcomp/article/view/574.

[3] W. Suharso, A. N. S. Widyanto, and Z. Sari, "Sistem Informasi Pelaporan Pada Uptd Pendidikan," J. INSTEK (Informatika Sains dan Teknol., vol. 3, no. 1, pp. 101-110, 2018, doi: 10.24252/instek.v3i1.4981.

[4] Y. Mulyati, Konsep Sistem Informasi, vol. 3, no. 1. 2005.

[5] P. Soepomo, "Perancangan Sistem Informasi Inventory Spare Part Elektronik Berbasis Web Php (Studi CV. Human Global Service Yogyakarta),” J. Sarj. Tek. Inform., vol. 2, no. 2, p. 10, 2014, doi: 10.12928/jstie.v2i2.2847.

[6] D. T. Octavian, "Desain Database Sistem Informasi Penjualan Barang," J. Teknol. dan Inform., vol. 1, no. 2, pp. $148-157,2013$.

[7] W. F. Eka, "Rancang Bangun Sistem Informasi Permintaan Atk Berbasis Intranet," J. Khatulistiwa Inform., vol. IV, no. 2, p. 41, 2016.

[8] Canggih Ajika Pamungkas, Buku Pengantar dan Implementasi Basis Data. Yogyakarta: Deepublish, 2017.

[9] S. Dharwiyanti and R. S. Wahono, "Pengantar Unified Modeling Language," IlmuKomputer, pp. 1-13, 2003, [Online]. Available: http://www.unej.ac.id/pdf/yanti-uml.pdf.

[10] D. Purnama Sari and R. Wijanarko, "Implementasi Framework Laravel pada Sistem Informasi Penyewaan Kamera (Studi Kasus di Rumah Kamera Semarang)," J. Inform. dan Rekayasa Perangkat Lunak, vol. 2, no. 1, p. 32, 2020, doi: 10.36499/jinrpl.v2i1.3190.

[11] I. P. Bagus, C. Desi, I. G. Suardika, G. Ngurah, and M. Nata, "Sistem Informasi Pengelolaan Bank Sampah di Desa Adat Pemogan Berbasis Framework Laravel," SAINTEKS, pp. 74-81, 2020.

[12] L. Y. Said, A. H. Jatmika, and I. W. A. Arimbawa, "Sistem Pendaftaran Hotspot Online Berbasis Web Menggunakan Mikrotik API, PHP, MySql Pada SMK Plus Nurul Hakim Kediri," J. Teknol. Informasi, Komputer, dan Apl. (JTIKA), vol. 1, no. 2, pp. 141-148, 2019, doi: 10.29303/jtika.v1i2.28.

[13] A. Solichin, MySQL Dari Pemula Hingga Mahir, 1.0. Jakarta, 2010.

[14] R. S. P. A. Pratiwi, R. U. Ginting, H. Situmorang, "Perancangan Sistem Informasi Akademik Berbasis Web di SMP Rahmat Islamiyah," TEKESNOS, vol. 2, no. 1, 2020.

[15] I. Tantowi, "Rancang Bangun Sistem Informasi TOEFL pada Pusat Bahasa Universitas Mataram," J. Teknol. Informasi, Komputer, dan Apl. (JTIKA ), vol. 1, no. 2, pp. 216-223, 2019, doi: 10.29303/jtika.v1i2.56. 